\title{
Estimation of Flavonoids and Screening of In Vitro Antioxidant Activities of Various Extracts of Aerial Parts of Cassia absus (Linn)
}

\author{
M. Mythri ${ }^{1}$, K. T. Sanal Dev², A. Kottai Muthu ${ }^{3}$ \\ ${ }^{1}$ Department of Pharmaceutical Chemistry, Alshifa College of Pharmacy, Perinthalmanna, \\ Malappuram, Kerala, India. ${ }^{2}$ Department of Pharmaceutical Chemistry, Alshifa College of Pharmacy, \\ Perinthalmanna, Malappuram, Kerala, India. ${ }^{3}$ Department of Pharmacy, Annamalai University, \\ Annamalainagar, Tamilnadu, India.
}

\section{ABSTRACT}

\section{BACKGROUND}

Free radicals are generated by both enzymatic and non-enzymatic reactions. The main source of free radicals in enzymatic reactions include those involved in phagocytosis, respiratory chain, in prostaglandin synthesis, and in cytochrome $\mathrm{p}^{450}$ system. Current investigation was to examine invitro antioxidant potential of Cassia absus (Linn).

\section{METHODS}

The aerial parts of Cassia absus (Linn) were powdered and the dry powder was subjected to extraction with various solvents (PE, EA and methanol) through Soxhlet extractor. The aerial parts of different concentrates (pet. ether, ethyl acetate and methanol) of Cassia absus was evaluated for its in-vitro antioxidant potential by hydroxyl radical, FRAP activity taking ascorbate used as standard for the both methods and total flavonoids content was estimated as equivalent to rutin.

\section{RESULTS}

The methanolic concentrates of Cassia absus \& standard exhibited antioxidant potential possessing $\mathrm{IC}_{50} 196 \mu \mathrm{g} / \mathrm{mL} \& 65 \mu \mathrm{g} / \mathrm{mL}$ (hydroxyl radical) $216 \mu \mathrm{g} / \mathrm{mL}$ \& $50 \mu \mathrm{g} / \mathrm{mL}$ (FRAP activity) respectively. Methanolic concentrates of Cassia absus were more efficient in hydroxyl radical, FRAP activity compared EA \& PE concentrates. The methanolic and EA concentrates of Cassia absus showed the total flavonoids content $(10.22 \pm 0.40,4.03 \pm 0.47$ respectively). The difference in scavenging potential of the extracts can be due to variation in the percentage of bioactive compound flavonoids present in methanolic extracts. Invitro antioxidant studies show that methanolic concentrates of Cassia absus have better antioxidant activity due to the presence of total flavonoids content.

\section{CONCLUSIONS}

This result indicates that methanolic concentrates of aerial parts of Cassia absus could serve as natural antioxidant, which may be useful in preventing free radical induced diseases.

\section{KEY WORDS}

Cassia absus, Hydroxyl Radical, FRAP, Flavonoids
Corresponding Author: Dr. A. Kottai Muthu, Department of Pharmacy, Annamalai University, Annamalainagar-608002, Tamilnadu, India.

E-mail: akottaimuthu@gmail.com

DOI: $10.14260 / j e m d s / 2020 / 491$

How to Cite This Article: Mythri M, Dev KTS, Muthu AK. Estimation of flavonoids and screening of invitro antioxidant activities of various extracts of aerial parts of cassia absus (Linn). J. Evolution Med. Dent. Sci. 2020;9(32): 2266-2269, DOI

$10.14260 /$ jemds $/ 2020 / 491$

Submission 26-02-2020,

Peer Review 02-07-2020,

Acceptance 08-07-2020,

Published 10-08-2020.

Copyright (c) 2020 JEMDS. This is an open access article distributed under Creative Commons Attribution License [Attribution 4.0 International (CC BY 4.0)] 


\section{BACKGROUND}

Free radicals are generated by both enzymatic and nonenzymatic reactions. The main source of free radicals in enzymatic reactions include those involved in phagocytosis, respiratory chain, in prostaglandin synthesis, and in cytochrome $\mathrm{p}^{450}$ system. Non-enzymatic reactions of oxygen with organic compounds as well as those initiated by ionizing radiations result in free radical production. ${ }^{1}$ Elimination and neutralization of ROS is handled by both enzymatic and nonenzymatic antioxidant mechanisms. The human body is in constant battle to keep from free radicals. The first line of defence is the preventive antioxidants which quench the free radicals generated in the body. An early stage Augmentation of antioxidant status should either prevent or greatly curtail tissue injury. ${ }^{2}$ Flavonoids \& Phenolic acids are known to act as antioxidant, not only for their good efficacy to donate hydrogen or electrons, but also their contribution as stable radical intermediates. ${ }^{3}$ The current trend of research is the investigation of medicines of plant origin which is affordable and access able with minimal side effects. As crude drugs of herbs and other plant materials rich in secondary metabolites like flavonoids, phenolic compounds, alkaloids etc are increasing interest in the pharmaceutical industry because they prevent the degradation of lipids and enhance their free radical scavenging potential thereby improving its medicinal values. $^{4}$

Cassia absus (Linn) (family c) is generally known as "chaksu" in ayurvedic traditional system. ${ }^{5}$ Chaksine and iso chaksine both alkaloids were isolated from seed of Cassia absus. ${ }^{6}$ Cassia absus was used for different diseases like antibacterial, antimalarial and lowering the blood pressure. ${ }^{7}$ Cassia absus was used antihistaminic activity of an eye drops $^{8}$.Still, no literature are available on the antioxidant activity of aerial parts Cassia absus. Thus, the present study to assess antioxidant activities of aerial parts Cassia absus.

\section{METHODS}

\section{Gathering \& Identification of Plant}

The aerial parts Cassia absus (family Fabaceae) were gathered form Senkottai, Tirunelveli District of Tamilnadu, India. Plant identification was made from Botanical investigation of India, Palayamkottai the Cassia absus were desiccated under shadowy, segregate, crushed through grinder. ${ }^{9}$

\section{Preparation of Concentrates}

The pulverized materials were packed in muslin cloth and extracted with pet. ether, ethyl acetate and methanol as solvents respectively according to the increasing order of polarity ${ }^{10}$ through hot constant percolation method in Soxhlet equipment ${ }^{11}$ for twenty-four hours. The concentrates were concentrated through rotational evaporator and subjected to solidify drying in a lyophilizer till dry powder was acquired. ${ }^{12}$

\section{Assessment of Antioxidant Potential through In Vitro Methods}

The variety of concentrates of aerial parts Cassia absus were used assessment of antioxidant activity by Elizabeth and Rao (1990)13 method was adopted for Hydroxyl radical assay \& Benzie and Strain (1996) ${ }^{14}$ was adopted for the FRAP assay and Cameron GR et al 1943 method described for total flavonoids content. 15

\section{RESULTS}

\section{Hydroxyl Radical Scavenging Activity}

Hydroxyl radical activity was expressed in terms of \% inhibition of generated free radicals respectively with respect to various concentrations. Hydroxyl radical potential of PE, EA and methanol extract of Cassia absus appeared Table 1. The more Hydroxyl radical potential of PE extract and standard at $800 \mu \mathrm{g} / \mathrm{mL}$ was recorded $49.64 \%$ and $84.37 \%$. $\mathrm{IC}_{50}$ of PE extract and standard was recorded as 820 $\mu \mathrm{g} / \mathrm{millilitre}$ and $65 \mu \mathrm{g} / \mathrm{millilitre}$ correspondingly. The more Hydroxyl radical scavenging potential of EA extract and standard $800 \mu \mathrm{g} / \mathrm{mL}$ was recorded $59.04 \%$ and $84.37 \%$ correspondingly. EA extract and Quercetin $\mathrm{IC}_{50}$ was recorded as $445 \mu \mathrm{g} / \mathrm{mL}$ and $65 \mu \mathrm{g} / \mathrm{mL}$ correspondingly.

\begin{tabular}{|c|c|c|c|c|c|}
\hline \multirow[b]{2}{*}{$\begin{array}{l}\text { Sl. } \\
\text { No. }\end{array}$} & \multirow{2}{*}{$\begin{array}{c}\text { Concentration } \\
\text { of Plant } \\
\text { Extract/ } \\
\text { Ascorbate } \\
(\mu \mathrm{g} / \mathrm{mL})\end{array}$} & \multicolumn{4}{|c|}{$\%$ of Effect $( \pm$ SEM)* } \\
\hline & & $\begin{array}{c}\text { PE } \\
\text { Extract }\end{array}$ & $\begin{array}{c}\text { EA } \\
\text { Extract }\end{array}$ & $\begin{array}{c}\text { Methanolic } \\
\text { Extract }\end{array}$ & Ascorbate \\
\hline 1 & 100 & $26.58 \pm 0.48$ & $33.76 \pm 0.013$ & $36.28 \pm 0.028$ & $57.34 \pm 0.024$ \\
\hline 2 & 200 & $32.41 \pm 0.26$ & $40.23 \pm 0.038$ & $49.92 \pm 0.034$ & $63.12 \pm 0.028$ \\
\hline 3 & 400 & $39.56 \pm 0.44$ & $51.18 \pm 0.076$ & $56.43 \pm 0.054$ & $71.40 \pm 0.033$ \\
\hline \multirow[t]{2}{*}{4} & 800 & $49.64 \pm 0.32$ & $59.04 \pm 0.052$ & $66.12 \pm 0.022$ & $84.37 \pm 0.018$ \\
\hline & & $\begin{array}{c}\mathrm{IC}_{50}=820 \\
\mu \mathrm{g} / \mathrm{mL}\end{array}$ & $\begin{array}{c}\mathrm{IC}_{50}=445 \\
\mu \mathrm{g} / \mathrm{mL}\end{array}$ & $\begin{array}{c}\mathrm{IC}_{50}=445 \\
\mu \mathrm{g} / \mathrm{mL}\end{array}$ & $\begin{array}{c}\mathrm{IC}_{50}=65 \\
\mu \mathrm{g} / \mathrm{mL}\end{array}$ \\
\hline & $\begin{array}{r}\text { Table } 1 . \\
\text { Cass }\end{array}$ & $\begin{array}{l}\text { tivity of } P E \\
\text { absus on } H\end{array}$ & $\begin{array}{l}\text { EA and Meth } \\
\text { droxyl Radi }\end{array}$ & $\begin{array}{l}\text { anol Extract } \\
\text { al Method }\end{array}$ & \\
\hline
\end{tabular}

Hydroxyl radical scavenging potential was more in methanolic extract and Quercetin (standard) at $800 \mu \mathrm{g} / \mathrm{mL}$ was recorded $66.12 \%$ and $84.37 \%$. Methanolic extract and standard $\mathrm{IC}_{50}$ was recorded as $196 \mu \mathrm{g} / \mathrm{mL}$ and $65 \mu \mathrm{g} / \mathrm{mL}$ correspondingly. $\mathrm{IC}_{50}$ values and Hydroxyl radical potential revealed that methanol extract of Cassia absus is better activity in scavenging superoxide radical when compared EA and PE extracts. The methanolic extract of Cassia absus exhibited higher ability in scavenging Hydroxyl radical when compared to the standard quercetin.

\section{FRAP Assay}

Ferric reducing ability of PE, EA and methanol extract Cassia absus and ascorbate were appeared in table 2. Reducing ability were expressed in terms of \% inhibition of generated free radicals respectively with respect to various concentrations. The more Reducing ability of PE extract and ascorbate $800 \mu \mathrm{g} / \mathrm{mL}$ were recorded $48.14 \%$ and $81.43 \%$. The $\mathrm{IC}_{50}$ of PE extract of Cassia absus and ascorbate were found as $865 \mu \mathrm{g} / \mathrm{mL}$ and $50 \mu \mathrm{g} / \mathrm{mL}$ correspondingly. 


\begin{tabular}{|c|c|c|c|c|c|}
\hline \multirow[b]{2}{*}{$\begin{array}{l}\text { Sl. } \\
\text { No. }\end{array}$} & \multirow{2}{*}{$\begin{array}{l}\text { Concentration } \\
\text { of Plant Extract/ } \\
\text { Ascorbate } \\
(\mu \mathrm{g} / \mathrm{mL})\end{array}$} & \multicolumn{4}{|c|}{$\%$ of Effect ( \pm SEM)* } \\
\hline & & $\begin{array}{c}\text { PE } \\
\text { Extract }\end{array}$ & $\begin{array}{c}\text { EA } \\
\text { Extract }\end{array}$ & $\begin{array}{c}\text { Methanolic } \\
\text { Extract }\end{array}$ & Ascorbate \\
\hline 1 & 100 & $31.54 \pm 0.032$ & $21.56 \pm 0.024$ & $437.34 \pm 0.022$ & $59.45 \pm 0.056$ \\
\hline 2 & 200 & $36.57 \pm 0.024$ & $32.50 \pm 0.032$ & $249.42 \pm 0.034$ & $64.56 \pm 0.034$ \\
\hline 3 & 400 & $43.64 \pm 0.016$ & $47.08 \pm 0.036$ & $662.44 \pm 0.012$ & $73.34 \pm 0.022$ \\
\hline \multirow[t]{2}{*}{4} & 800 & $48.14 \pm 0.065$ & $59.12 \pm 0.042$ & $269.44 \pm 0.028$ & $81.43 \pm 0.062$ \\
\hline & & $\begin{array}{c}\mathrm{IC}_{50}=865 \\
\mu \mathrm{g} / \mathrm{mL}\end{array}$ & $\begin{array}{c}\mathrm{IC}_{50}=498 \\
\mu \mathrm{g} / \mathrm{mL}\end{array}$ & $\begin{array}{c}\mathrm{IC}_{50}=216 \\
\mu \mathrm{g} / \mathrm{mL}\end{array}$ & $\begin{array}{c}\mathrm{IC}_{50}=50 \\
\mu \mathrm{g} / \mathrm{mL}\end{array}$ \\
\hline & $\begin{array}{r}\text { Table 2. Red } \\
\text { Met }\end{array}$ & $\begin{array}{l}\text { ucing Ability } \\
\text { hanol Extrac }\end{array}$ & $\begin{array}{l}\text { of Cassia al } \\
t \text { by FRAP M }\end{array}$ & $\begin{array}{l}\text { bsus PE, EA at } \\
\text { Method }\end{array}$ & \\
\hline
\end{tabular}

The more Ferric reducing ability of EA extract and ascorbate $800 \mu \mathrm{g} / \mathrm{mL}$ was recorded $59.12 \%$ and $81.43 \%$. The $\mathrm{IC}_{50}$ value of ethyl acetate extract of Cassia absus and ascorbate were found $498 \mu \mathrm{g} / \mathrm{mL}$ and $50 \mu \mathrm{g} / \mathrm{mL}$ correspondingly. The more Ferric reducing ability of methanolic extract and ascorbate $800 \mu \mathrm{g} / \mathrm{mL}$ were recorded $69.44 \%$ and $81.43 \%$. The $\mathrm{IC}_{50}$ value of methanol extract of Cassia absus and ascorbate was recorded as $216 \mu \mathrm{g} / \mathrm{mL}$ and $50 \mu \mathrm{g} / \mathrm{mL}$ correspondingly.

$\mathrm{IC}_{50}$ values and Ferric reducing ability revealed that methanol extract of Cassia absus is huge activity in Ferric reducing ability when compared ethyl acetate and petroleum ether extract. But when compare to the all the three extract, the methanol extract of the Cassia absus showed the better result.

\section{Total Flavonoids}

The total amount of flavonoid content of various extract of aerial plant of Cassia absus was present in Table 3. The EA and methanolic extract of Cassia absus were found $3.438 \pm$ 0.32 and $9.618 \pm 0.64$ correspondingly.

\begin{tabular}{|ccc|}
\hline $\begin{array}{c}\text { Sl. } \\
\text { No. }\end{array}$ & Extracts & $\begin{array}{c}\text { Total flavonoids content } \\
\text { (mg Rutin/g) ( } \pm \text { SEM) }\end{array}$ \\
1 & Petroleum ether extract of Cassia absus & $0.176 \pm 0.45$ \\
2 & Ethyl acetate extract of Cassia absus & $3.438 \pm 0.32$ \\
3 & Methanolic extract of Cassia absus & $9.618 \pm 0.64$ \\
& *All values are expressed as mean \pm SEM for three determinations \\
\hline \multicolumn{3}{|c|}{ Table 3. Total Flavonoids Content of Various Extracts } \\
of Aerial Parts of Cassia absus
\end{tabular}

Based on the result the methanolic extract of Cassia absus was found higher content of flavonoid than that of PE and EA extract of Cassia absus.

\section{DISCUSSION}

Hydroxyl radical is the most ROS and causes severe injure to adjacent biomolecule. Hydroxyl radical scavenging activity was estimated by generating the hydroxyl radicals using ascorbic acid-iron EDTA. The hydroxyl radicals were produced by the oxidation reaction with the DMSO to give in HCHO, which provides a suitable method to identify hydroxyl radicals by treatment with Nash reagent. ${ }^{16}$ Among the three different plant concentrates tested, interestingly, in the $\mathrm{OH}$ radical activity of the methanol extract of Cassia absus exhibited more $\mathrm{OH}$ radical potential comparable with that of ascorbic acid. The FRAP assay measures the reducing potential of an antioxidant reacting with a ferric tripyridyl triazine ( $\mathrm{Fe}_{3}+$-TPTZ) complex and produce a coloured ferrous tripyridyl triazine $\left(\mathrm{Fe}_{2}+-\mathrm{TPTZ}\right){ }^{12}$ Generally, the reducing properties are linked with the presence of compounds which exert their action by breaking free radical chain by donating a hydrogen atom. ${ }^{17}$ Total antioxidant potential of methanol extract of Cassia absus exhibited higher ability in scavenging compared to ascorbic acid. The antioxidant activity of phenolics and flavonoids is largely due to their redox properties which make them act as reducing agents, hydrogen donors, singlet oxygen quenchers and as well as potential metal chelators. ${ }^{18}$ Among the three various extracts, methanolic extract of Cassia absus exhibited higher potency of antioxidant activity due to presence of total flavonoid compounds.

\section{CONCLUSIONS}

Among the three extracts, methanolic extract of Cassia absus exhibited higher potency of antioxidant activity due to presence of total flavonoid compounds. These results indicate that methanolic extract of aerial parts of Cassia absus could serve as a natural antioxidant, which may be useful in preventing free radical induced diseases.

Financial or Other Competing Interests: None.

\section{REFERENCES}

[1] Liu T, Stem A, Roberts LJ. The isoprostanes: novel prostanglandin-like products of the free radical catalyzed peroxidation of arachidonic acid. J Biomed Sci 1999;6(4):226-35.

[2] Lobo V, Patil A, Phatak A, et al. Free radicals, antioxidants and functional foods: impact on human health. Pharmacogn Rev 2010;4(8):118-26.

[3] Ammar RB, Bhouri W, Sghaier MB, et al. Antioxidant and free radical-scavenging properties of three flavonoids isolated from the leaves of Rhamnus alaternus $\mathrm{L}$. (Rhamnaceae): a structure - activity relationship study. Food Chem 2009;116(1):258-64.

[4] Lagarda MJ, Garcia-Llatas G, Farre R. Analysis of phytosterols in foods. Journal of Pharmaceutical and Biomedical Analysis 2006;41(5):1486-96.

[5] Kirtikar KR, Basu BD. Indian medicinal plants. Vol. 2. Bahadurganj, India: Sudhindra Nath Basu Publishers 1918: p. 873.

[6] Siddiqui S, Ahmed Z. Alkaloids from the seeds of cassia absus. Proc Math Sci 1935;2:421-5.

[7] Aftab K, Ahmed SI, Usmanghani K, et al. Traditional medicine cassia absus L. (Chaksu)-pharmacological evaluation. Phytomedicine 1996;2(3):213-9.

[8] Abdul L, Abdul R, Sukul RP, et al. Anti-inflammatory and antihistaminic study of a Unani eye drops formulation. Ophthalmol Eye Dis 2010;2:17-22.

[9] Kumar DS, Muthu AK, Smith AA, et al. Free radical scavenging activity of various extracts of whole plant of Mucuna pruriens (Linn): an in-vitro evaluation. Journal of Pharmacy Research 2010;3(4):718-21. 
[10] Shajiselvin CD, Muthu AK. In- vitro antioxidant studies of various extracts of whole plant of Borreria hispida (Linn). Research Journal of Biological Pharmaceutical Chemical Sciences 2010;1(2):14-20.

[11] Borse LB, Muthu AK, Thangatripathi A, et al. Antimicrobial activity of heartwood of Tecoma stans. International Journal of Pharmacy and Pharmaceutical Sciences 2012;4(3):384-6.

[12] Kumar DS, Muthu AK, Smith AA, et al. Hypolipidemic effect of various extracts of whole plant of Mucuna pruriens (Linn) in rat fed with high fat diet. European Journal of Biological Sciences 2010;2(2):32-8.

[13] Benzie IF, Strain JJ. The ferric reducing ability of plasma (FRAP) as a measure of "antioxidant power": the FRAP assay. Anal Biochem 1996;239(1):70-6.
[14] Kunchandy E, Rao MNA. Oxygen radical scavenging activity of curcumin. Int J Pharm 1990;58(3):237-40.

[15] Cameron GR, Milton RF, Allen JW. Measurement of flavonoids in plant samples. Lancet 1943; p. 179.

[16] Pavithra K, Vadivukkarasi S. Evaluation of free radical scavenging activity of various extracts of leaves from Kedrostis foetidissima (Jacq.) Cogn. Food Science and Human wellness 2015;4(1):42-6.

[17] Duh PD, Du PC, Yen GC. Action of methanolic extract of mung bean hulls as inhibitors of lipid peroxidation and non-lipid oxidative damage. Food Chem Toxicol 1999;37(11):1055-61.

[18] Pietta PG. Flavonoids as antioxidants. J Nat Prod 2000;63(7):1035-42. 